\title{
斐伊川河口部における水位上昇の原因と その発生メカニズムに関する考察 THE CAUSE AND MECHANISM OF WATER LEVEL RISE NEAR THE MOUTH OF THE HII RIVER
}

\author{
船橋昇治 ${ }^{1} \cdot$ 渡辺茂 $^{2} \cdot$ 福岡捷二 ${ }^{3}$ \\ Shoji FUNABASHI , Shigeru WATANABE and Shoji FUKUOKA \\ 1正会員 国土交通省中国地方整備局河川部河川調査官（干730-8530 広島市中区上八丁堀6-30） \\ 2正会員 工修 国土交通省中国地方整備局出雲河川事務所長（广693-0023 島根県出雲市塩冶有原5-1） \\ 37 叶会員 工博 中央大学研究開発機構教授（干112-8551 東京都文京区春日1-13-27）
}

\begin{abstract}
The water level near the mouth of the Hii River was over the design high water level in the 2006 July flood .The cause and mechanism of water level rise near the river mouth must be clarified from the fact that higher water level had been recorded as well in the past floods. It is shown from data analysis that the rise of water level results from the variation of bed and dune heights near the mouth with increase in flood discharge and water level of the Lake of Shinji. This mechanism was also proved by the one dimensional computation of flood flow and bed variation.
\end{abstract}

Key Words : 2006 flood, high water level, bed variation, river mouth, dune bed

\section{1. はじめに}

斐伊川は、中国山地に端を発し宍道湖、中海を経て日 本海に注ぐ一級河川である。斐伊川の河口（宍道湖）か ら約 $20 \mathrm{~km}$ は天井河川となっており、その原因は、河床 に大量の砂が堆積しているためである。また、斐伊川が 注ぐ宍道湖は、水はけが悪く出水時にはその水位が上昇 する。これらの要因が複雑に関連して、斐伊川の下流部 では、他区間に比べ洪水時にしばしば水位上昇が見られ る。平成18年 7 月の豪雨では、宍道湖までの斐伊川直轄 区間における 6 水位観測所の全てが観測史上最高の水位 を記録した。特に、宍道湖に最も近い灘分観測所では計 画高水位を $67 \mathrm{c} \mathrm{m}$ 超過した。今回の出水が斐伊川下流 部における計画規模相当の洪水であり、河口付近など一 部区間だけで計画高水位を超過したこと及び灘分観測所 のみが他の出水の際にも頻繁に高い水位が観測されてい ることから、今回の出水に関して、洪水の最中の河床高 のデータや洪水後の河道横断測量等のデータはないが、 現時点で得られているデータをもとに、斐伊川河口部に おける水位上昇の原因とその発生メカニズムについて考 察する。

\section{2. 斐伊川と洪水の概況}

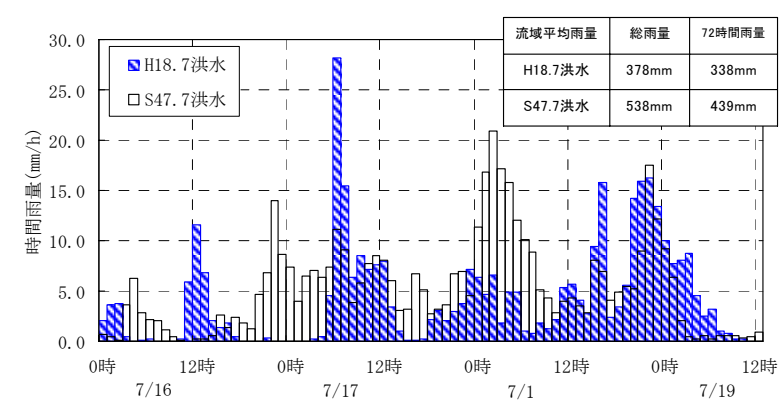

図-1＼cjkstart斐伊川流域のハイエトグラフ

\section{（1）降雨と洪水の概況}

平成18年 7 月 16 日から19日にかけての前線による降雨 は、日本海沿岸に南下した梅雨前線が偏西風帯のうねり にあわせて停帯したため、前線に高温多湿な空気（湿 舌）が流れ込み続けたことが原因となり、山陰を中心と する中国地方に大きな被害をもたらす豪雨となった。 斐伊川流域における降雨状況は図-1のとおりである。 当地方で大きな浸水被害が発生した昭和 47 年 7 月豪 雨と比較すると、総雨量が及ばなかったため、宍道湖の 水位は昭和 47 年に次ぐ記録であったが、降雨の集中度 合いは今回の方が強かった。この結果、大津観測所（河 口から $12.5 \mathrm{~km})$ では、約 $2,400 \mathrm{~m}^{3} / \mathrm{s}$ を記録し、計画高 水流量と同規模の洪水となった。 


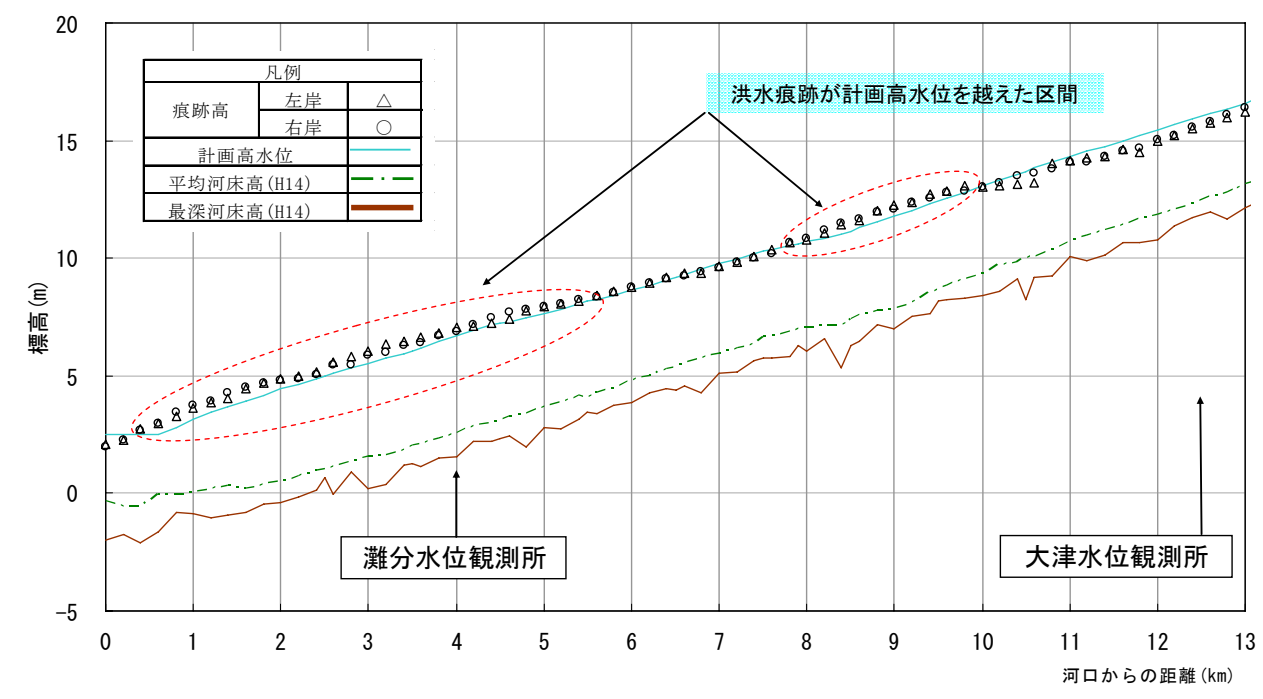

図-2 斐伊川痕跡水位縦断図

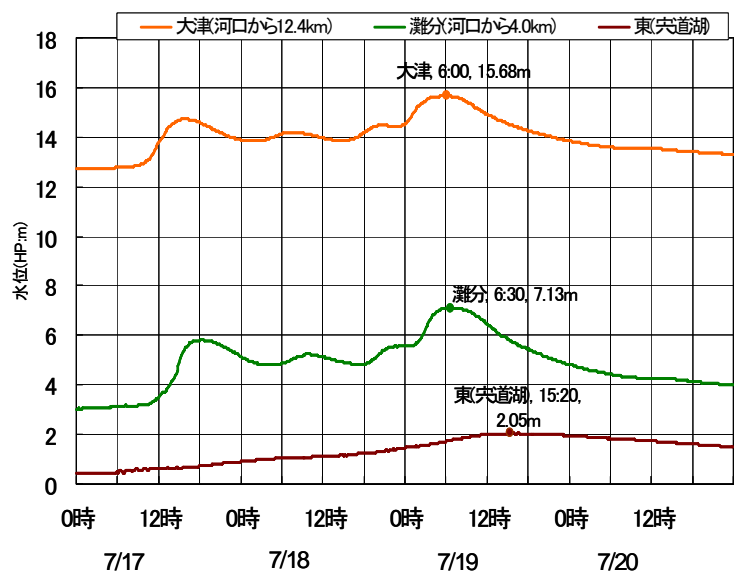

図-3 宍道湖（東）と灘分の水位の経時的変化

当出水による斐伊川の痕跡水位は図-2のとおりである。 今回の出水は、大津地点下流において計画高水流量 相当の大出水であり、痕跡水位は、図-2 のとおり全般 的には計画高水位程度となっているが、宾道湖河口から $6 \mathrm{~km}$ まで及び $8 \mathrm{~km}$ から $10 \mathrm{~km}$ までの 2 区間において計画 高水位を超過している。今回の出水で観測された水位を 経時的に示したのが、図-3である。

今回の出水は、河川水位の第一ピークを迎えてから最 終ピークを迎えるまでの約 36 時間比較的大きな洪水が 続き、最終ピークにおける流量が最も大きな洪水であっ た。このため、宾道湖の水位は、48時間以上にわたり 上昇し続け、洪水前に比べ最高約 $1.7 \mathrm{~m}$ 上昇した。なお、 灘分観測所の水位がピークを記録した19日午前 6 時 30 分 時点でも、宍道湖水位は約 $1.5 \mathrm{~m}$ 上昇しており、この時の 水位高は灘分観測所の最深河床高程度に相当する。また、 大津観測所に比-灘分観測所では水位の立ち上がりが遅 れるとともに急になっていることが分かる。

\section{（2）斐伊川の現況及び特徵}

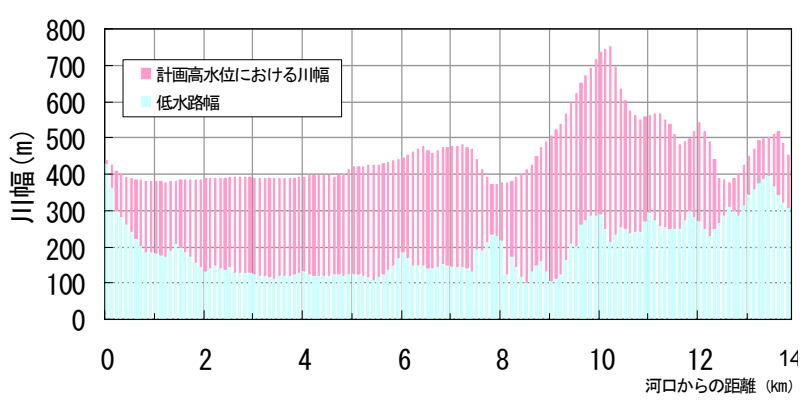

図-4 川幅の比較

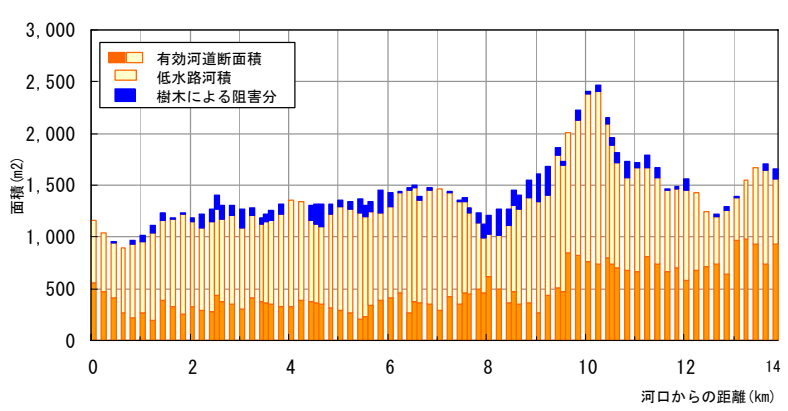

図-5 河道断面積の比較

斐伊川の河道の特徴について、整理した結果を図-4〜 6に示す。

図-4は、斐伊川の低水路部と計画高水位の高さにおけ る川幅を縦断的に示したものである。低水路幅は、昭和 20 年代から、低水路を狭く寸る工事を $2 \mathrm{~km}$ 况 $8 \mathrm{~km}$ 区間 において実施したことから、取水樋門がある箇所を除い てほぼ120mとなっているが、 $2 \mathrm{~km}$ から河口までは積極的 な低水路工事を実施していないため、低水路幅が120mか ら400mにラッパ状に広がった形状をしている。

図-5は河道の断面積を低水路部分だけと高水敷分も含 めた面積と樹木によって阻害されている面積に分けて整 


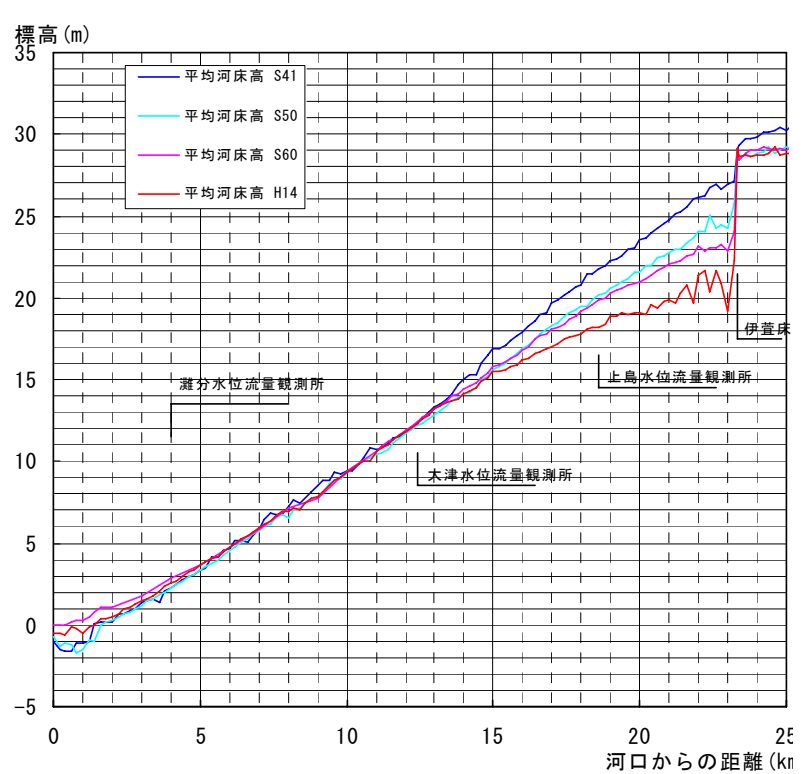

図-6 平均河床高の比較

理したものである。図-5より樹木を除いた洪水疎通に有 効に機能する河道断面積は、その前後の区間と比較して $8.0 \mathrm{~km}$ 付近で極端に小さく、0.6km付近もやや小さいこと が分かる。

図-6は低水路の平均河床の経年的変化を縦断的に比較 したものである。砂利採取を昭和49年に禁止し、昭和61 年までほとんど河床掘削を行っていないが、それ以降は 維持掘削を実施している。このため、下流部の河床高は 昭和60年が最も高く、その後低下している。斐伊川の河 床材料は河口までほぼ均質で平均粒径 $2 \mathrm{~mm}$ 砂を中心に 構成されている。こうした砂はかつて砂鉄を採取するた めに花崗岩質の山を切り崩し、砂鉄を取り終えた後の砂 を廃砂した鉄穴流しに由来寸るものである。鉄穴流しに より人為的に大量に河床に堆積した砂は、斐伊川の河床 勾配とバランスがとれた河床材料より粒径が小さい。こ のため、図-6からも分かるように、自然な状態では河床 材料は下流一移動し河口付近で掃流力が小さくなり堆積 するため、河床勾配は全体を通して現在より緩やかにな る。特に、伊萱床止めの下流で急激に河床低下が起こり、 床止めから下流になればなるほどその程度は小さくなり、 $8 \mathrm{~km}$ から15km地点ではほぼ安定しており、8 kmから下流 においては河口に近づくほど堆積傾向にある。この河床 材料の移動は、大洪水時のみならず年間頻繁に発生する 小さな出水時にも見られる。

\section{3. 水位上昇の原因とその発生メカニズム}

\section{（1）水位上昇の原因}

前章で整理された斐伊川の河道特性より、8kmから $10 \mathrm{~km}$ 区間で計画高水位を超えるような水位上昇が発生し ているのは、 $8 \mathrm{~km}$ 付近の川幅が狭く有効河道断面積が上 表-1＼cjkstart灘分と大津観測所の過去高水位記録

\begin{tabular}{|c|c|r|c|r|}
\hline \multirow{2}{*}{$\begin{array}{c}\text { 順 } \\
\text { 位 }\end{array}$} & \multicolumn{2}{|c|}{ 灘分水位観測所 } & \multicolumn{2}{|c|}{ 大津水位観測所 } \\
\hline \hline 1 & 平成18年7月19日 & $\begin{array}{c}\text { ピーク水位 } \\
(\mathrm{m})\end{array}$ & 発生年月日 & $\begin{array}{c}\text { ピ一ク水位 } \\
(\mathrm{m})\end{array}$ \\
\hline 2 & 昭和58年9月28日 & 4.37 & 平成18年7月19日 & 3.45 \\
\hline 3 & 平成10年10月18日 & 4.54 & 昭和20年9月18日 & 昭和47年7月11日 \\
\hline 4 & 平成5年9月4日 & 4.37 & 平成10年10月18日 & 3.07 \\
\hline 5 & 平成16年10月20日 & 4.27 & 平成5年9月4日 & 3.00 \\
\hline
\end{tabular}

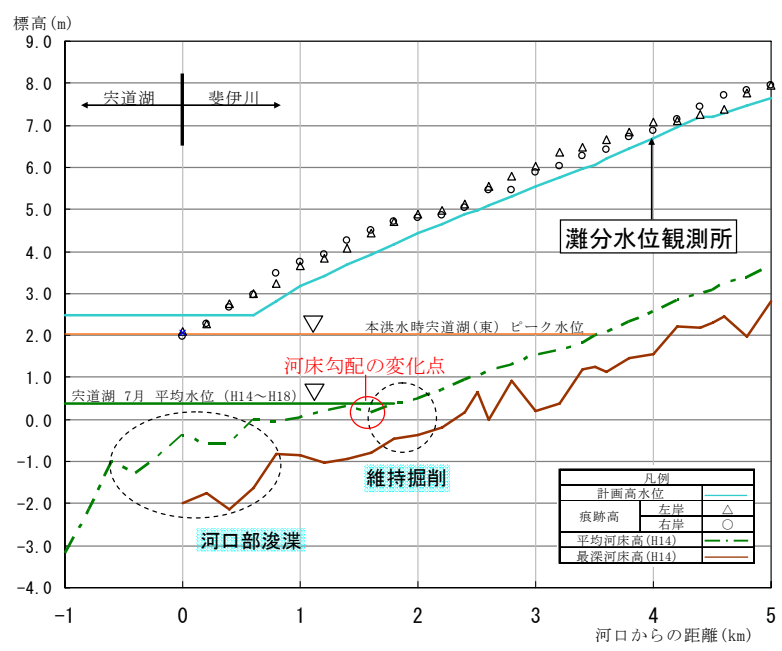

図-7＼cjkstart斐伊川河口部の河床高と宾道湖水位との関係

下流区間に比べて極端に小さいことによる堰上げが主な

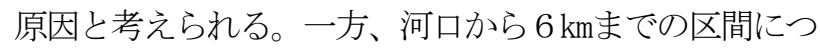
いては、0.6km付近の有効河道断面積が小さいことも原 因の一つと考えられるが、痕跡水位が $0.6 \mathrm{~km}$ 地点より下 流で既に急上昇していること及び、その上流約 $5 \mathrm{~km} に わ ~$ たる広範囲で水位上昇が見られることから、他にも大き な理由があると考えられる。事実、灘分観測所（河口か ら $4 \mathrm{~km})$ と大津観測所において、これまで水位が高かっ た洪水を比較すると表-1のように明らかに異なる結果を 示している。

両観測所の間には、流入支川が全くないため、両観測 所で水位が高くなる洪水が異なるということは、流量だ けではなく他の要因が存在していると考えられる。一つ の理由としては、昭和58年 9 月洪水に代表されるような 下流部の堆積による河床の上昇があげられよう。しかし ながら、昭和62年以降は毎年維持掘削等を行い、最近で は宾道湖内を含む河口部 $(-0.5 \sim 0.5 \mathrm{~km}$ 区間 $)$ で年間 10 万的強の浚渫を行っており、今回の洪水前に著しく堆積 していた事実はない。（図-7参照）つまり、河口から6 $\mathrm{km}$ 区間における水位上昇を引き起こすような原因は洪水 前に見当たらない。こうしたことから、洪水の最中にお ける河床の変化が水位上昇に影響したものと思われる。

\section{（2）本洪水の特徴}

今回の洪水では、洪水中の河床の高さは計測されて おらず、洪水中に定量的に計測されたデータは、灘分観 


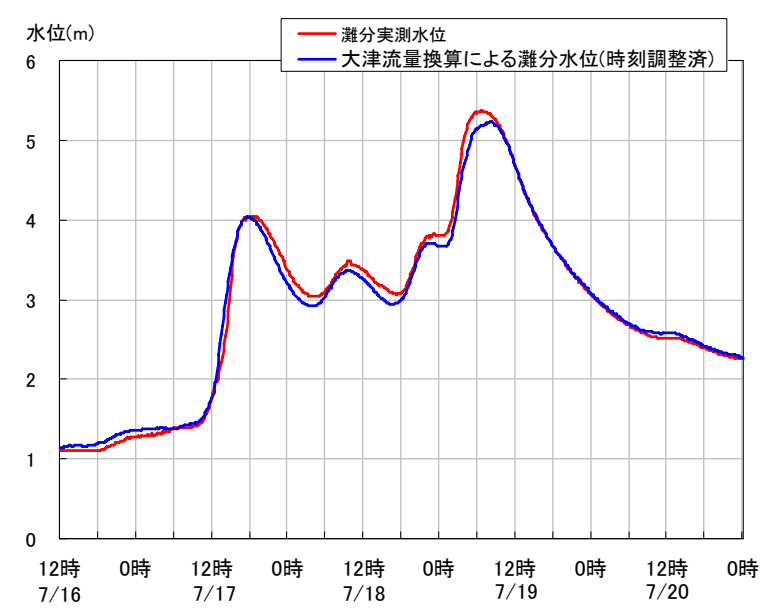

図-8＼cjkstart灘分観測所の実測水位と大津流量から換算した水位

測所と大津観測所における水位と流量のみである。これ らのデータを用いて今回の洪水の特徵を分析してみる。

大津観測所と灘分観測所の間には流入支川が全くない ことから、大津観測所で観測された流量が、そのまま灘 分観測所に到達したと仮定した際に灘分観測所で観測さ れるはずの水位と実際に灘分観測所で観測された水位を 比較したものが図-8である。

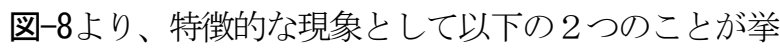
げられる。

現象(1) : 水位の第一ピークに至る前の 7 月 17 日13時〜 16時の間は灘分実測水位の方が流量から換算 した水位より下がっていること

現象(2)：7月17日の18時頃の水位の第一ピークから 7 月19日の 8 時頃の最終ピークまでの間の灘分 実測水位の方が大津流量から換算した水位よ り約 $30 \mathrm{~cm}$ 高いこと

また、灘橋（河口から $2 \mathrm{~km}$ ）付近における洪水前後の 航空写真を写真-1に示す。洪水前後の河床形態は複列砂 州であるが、洪水時には砂州の上に大きな砂堆が発生す $3^{1,2)}$ 。今回の水理量を用いて河床形態を検討寸ると流 量ピーク時には砂堆となっている。写真-1の洪水前後の 写真の比較から、砂州と砂堆の大きさが洪水前に比べて 洪水後は大きく成長していることが確認できる。

\section{（3）洪水時の河床変動}

これらのデータ及び写真を踏まえ、洪水時の河床変動 状況について、次の 4 つ観点から考察する。

\section{a）河川流量増大による影響の観点}

河川流量が増大寸ると水深が増大し、掃流力も増大し ていく。この現象は、全区間で全般的に言えることであ るが、 $2 \mathrm{~km}$ から $8 \mathrm{~km}$ 区間は各種流量（計画高水流量、融 雪流量、平水流量）で掃流力がほぼ同一になるよう河道 設計されており ${ }^{3)}$ 、河床の動的平衡が保たれていること から堆積や洗掘現象は起こりづらいが、その他の区間で はこの影響が現れると思われる。特に、河口付近では、
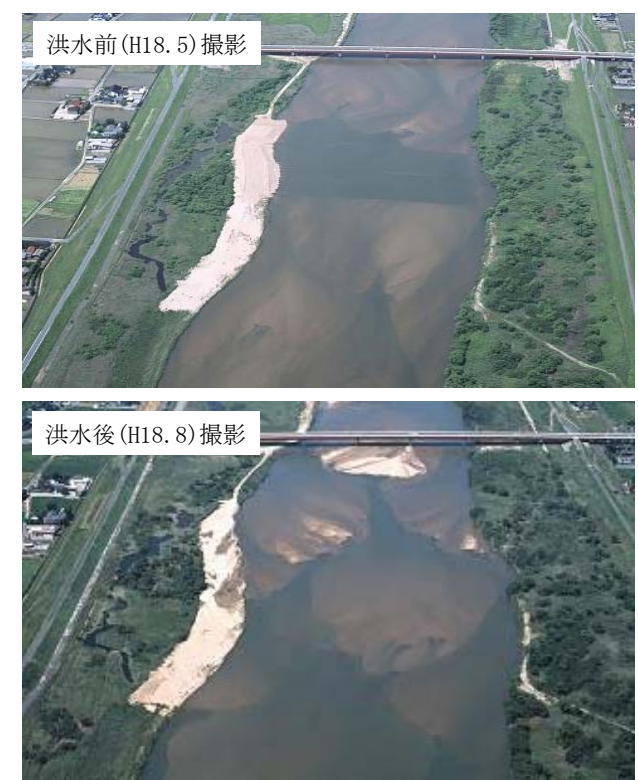

写真-1 灘橋(河口から2km) 付近の洪水前後の斐伊川の状況

平常時に宾道湖の水位と河川流量でバランスがとれてい た河床状態における河床勾配の変化点（図-7の円で囲ん だ箇所）が洪水時に掃流力の増大により宍道湖側に移動 することにより、勾配変化点より下流区間では河床低下 が発生すると考えられる。また、河川流量の増大と实道 湖水位の上昇が重なった場合には、掃流力の増大が顕著 な区間は下流から更に上流まで拡がると考えられる。

b）河口付近の低水路平面形状の変化による影響の観点

$2 \mathrm{~km}$ から $8 \mathrm{~km}$ 区間は低水路幅が $120 \mathrm{~m}$ でほぼ一定なた め掃流砂は動的平衡状態になっているが、 $2 \mathrm{~km}$ から下 流については、低水路幅が急に拡がるため、平均水深が 変化し、 $2 \mathrm{~km}$ のすぐ下流では土砂堆積が起こりやすい 状況にある。

\section{c）宾道湖水位上昇による影響の観点}

洪水期間中に上流から下流に土砂が移動しているが、 宍道湖の水位が上昇するのに連動して、宍道湖の背水の 影響を受け流速が低減して土砂が移動しづらくなる（堆 積する）ポイントが上流へ移動していくことになる。

\section{d）洪水の継続時間の観点}

洪水がある規模以上で長時間継続することにより、砂 堆の成長が促進され、砂堆の高さが大きくなる。こうし た区間では、河床面に作用するせん断抵抗分だけでなく 砂堆の拡大による形状抵抗分が付加され、結果的に河床 の抵抗が増大し水位が上昇しやすくなる ${ }^{3)}{ }^{4)}$ 。

これらの 4 つの観点から起こりうる事象を時系列的に 整理すると次のようになる。

(1)まず、实道湖の水位が上昇する前に急激に河川流 量が増え、河床勾配の変化点が下流に移動（河口 付近の河床が低下）する（前述の現象(1)はこれが 原因で発生)

(2)上流から移動してきた砂が $2 \mathrm{~km}$ 地点の下流部で堆 積し、その後中規模の洪水が 36 時間以上続いたこ 

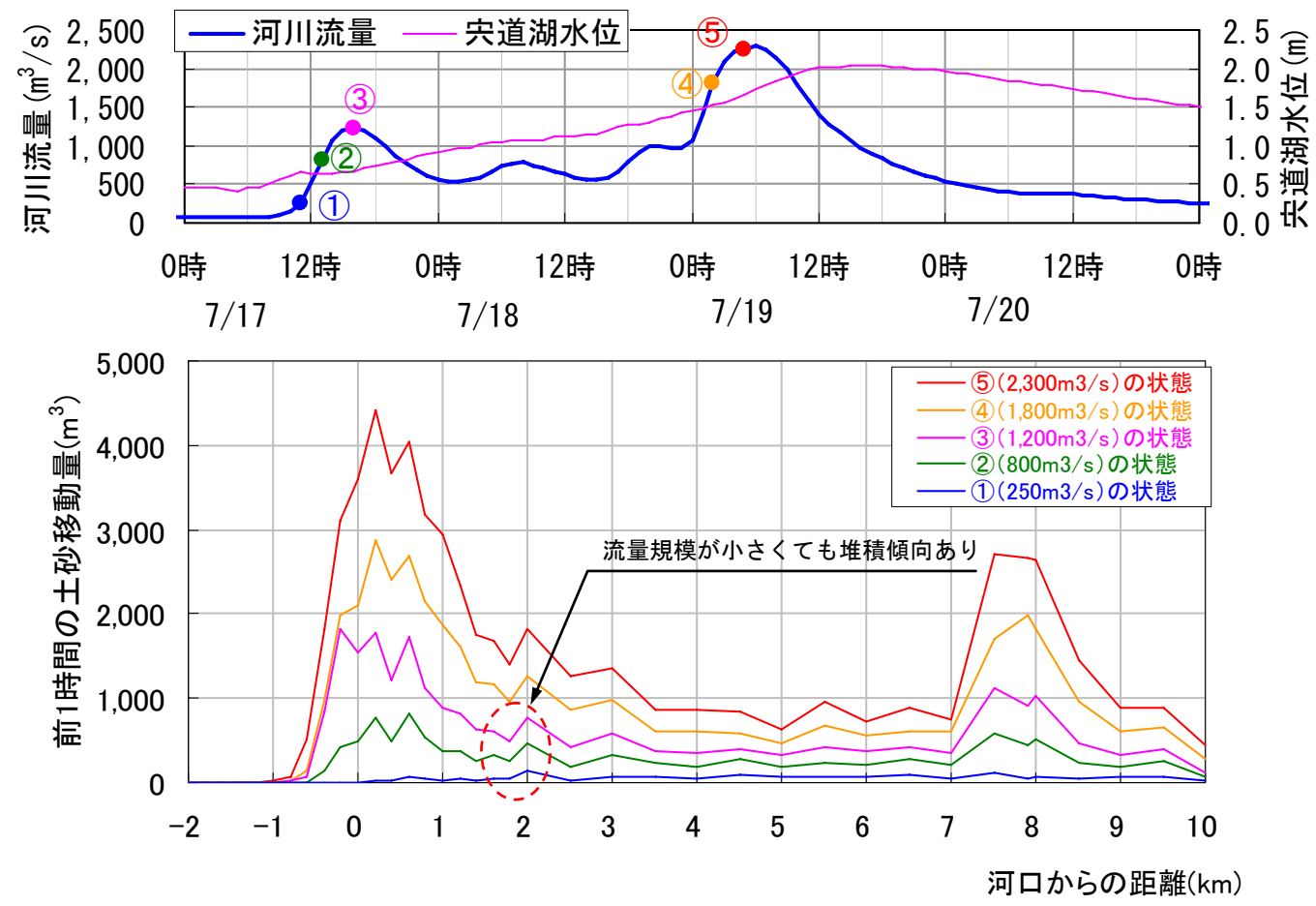

図-9 洪水流量と土砂移動量の関係

とによりこの区間の堆積が十分進むとともに、そ の上流区間では砂堆の成長が促進される

(3)さらに、 $2 \mathrm{~km}$ 地点下流部の堆積により、大型化し た砂堆の下流への移動が起こりづらくなる（前述 の現象(2)、(2)と(3)が主な原因で発生)

こうした河床変動が発生した結果、河口付近では河床 勾配の変化点が下流に移動し河床が下がる一方で、その 上流では堆積や砂堆の成長が促進され、水位が上昇しや

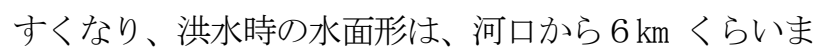
でが他に比べて上昇し、計画高水位を超えたと考えられ る。

\section{（4）河床変動の検証}

本出水における平均的な河床の高さについて、観測さ れているデータと痕跡水位をもとに計算を行った。

\section{a）河床変動発生要因の検証}

時間変化とともに河床がどのように変化し得るのか傾 向を確認するため、本出水で実際に観測された宍道湖水 位と大津観測所の河川流量（図-9 の上段図）を与条件 として変化させながら、斐伊川の一元河床変動による土 砂移動量の計算を行った結果が図-9 である。上段の図 が計算を行った条件を示し、下段の図がその条件下 1 時 間での土砂移動量を縦断的に示した結果である。なお、

これまでも斐伊川では一元河床変動計算の適合度は高い とされている。この計算結果より、次のような事象が確 認された。

(1)河口付近では洪水流量の増加に伴い、土砂移動量 が増大し、宍道湖水位が高いほど土砂移動が活発
になる区間は上流に拡がる。（(3)の a）の観点を 検証)

(2) $2 \mathrm{~km}$ の下流の $1.8 \mathrm{~km}$ では、(1)の事象ほどは流量規 模に左右されず常に堆積傾向を示した。（図-9の だ円で囲んだ箇所参照：(3)のb）の観点を検証）

当結果より、洪水流量の増大に伴い掃流力が増し、河 口付近では河床低下が発生するとともに、流量と穴道湖 水位の上昇により土砂堆積が飛躍的に活発になり、その 範囲が上流にまで拡大し、 $4 \mathrm{~km}$ 付近まで河床材料が移 動しやすくなっていることと、1. $8 \mathrm{~km}$ 地点は低水路形状 の変化により常に河床に土砂が堆積しや寸い傾向にある ことが計算より明らかになった。

\section{b）洪水痕跡からの検証}

ピーク水位発生時にどのような河床高となっているは ずであるかを確認するため、a）の河床変動発生要因の 検証で明らかになったことを踏まえ、今回の出水におい て灘分地点の高水流量観測にて観測した最大流量が定常 的に流れた場合の計算水位が、縦断的に確認されている 痕跡水位と一致するように河床の高さを洪水前の河床の 高さに対して上下させて計算を行った" 高かったケースを図-10に示寸。なお、低水路粗度につ いては、河床材料がほぼ一様であることから、高水敷の 植生状況を極力正確に準二次元不等流計算に反映させ、 全般的に適合度の良いケースから逆算して求めた数值 0.04を用いた。図-10より、河口付近 $(0 \sim 1.2 \mathrm{~km})$ では河 床高が0. $4 \mathrm{~m}$ 程度低下し、 $2 \mathrm{~km}$ 地点下流(1.4 1.8km) では 逆に0. $4 \mathrm{~m}$ 程度河床高を上昇させたケースが最も適合度が よかった。 


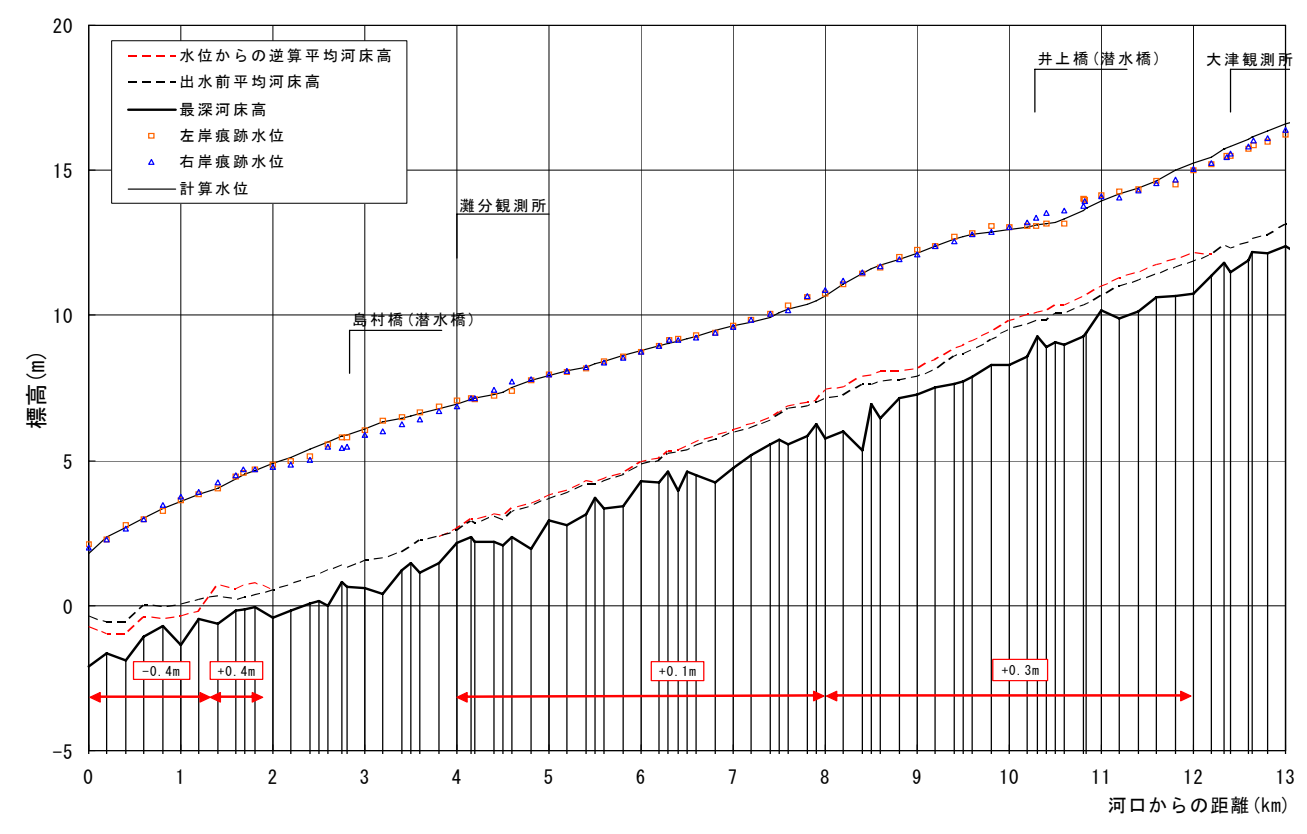

図-10 洪水流量と土砂移動量の関係

この計算結果から、(3)のa)及びb)の観点が検証でき たと考える。また，斐伊川の河床材料から判断すると低 水路粗度0.04は大きく、(3)のd)の影響が出ていると推 測される。

さらに、マクロ的には河川流量の増大と宍道湖水位 の上昇という非定常な現象により河口付近の河床高が低 下寸る一方で、低水路の形状的な変化の影響等により、 $2 \mathrm{~km}$ 地点下流区間 $(1.4 \sim 1.8 \mathrm{~km})$ で堆積が進行し、その程 度は数 $10 \mathrm{~cm}$ オーダーであることが明らかになった。

こうした観測されたデータを基にした計算結果は、前 節で述べた斐伊川下流部で発生している現象として河川 水位に影響を及ぼす河床変動に関する 4 つの観点と符合 している。

\section{4. 終わりに}

以上のように斐伊川の河口部を中心とした下流部の 河床が、洪水時の流量規模や宾道湖水位及び洪水のパ ターンなどの要因によって、複雑に変動していることが 明らかになった。

(1)宍道湖水位が上昇寸る前に河川流量が増えると、

掃流力が増し、河床勾配の変化点が下流に移動

し、河口付近の河床が数 $10 \mathrm{~cm}$ オーダーで低下寸 る。

(2)低水路幅が広くなる $2 \mathrm{~km}$ 地点の下流部で河床材料 が堆積しやすく、その堆積の程度は数 $10 \mathrm{~cm}$ オー ダーである。

(3)中規模の洪水が長時間続くと、砂堆の成長が促進 される。

本考察は、現時点で得られている情報をもとに行った
が、今後得られる今回の出水データを踏まえ、今回の考 察結果を再確認しなければならない。

今回の出水の前には宾道湖内を含む河口部の浚渫が十 分行われており、洪水の際に河口部の河床勾配の変化点 の下流への移動が比較的起こりやすかったと推測される。 しかしながら、海へ流れ込む河川では、河口出口の先で 急に水深が深くなるため、洪水のたびに掃流砂が河口部 に堆積し続けることはないが、湖に流れる斐伊川ではこ うした浚渫が十分行われていない場合に、どのような影 響がでるのかについても明らかにする必要がある。さら に、洪水時の河床変動の状況を定量的に明らかにし、そ の影響の程度も様々な洪水パターンについて検討する必 要がある。このため、洪水中の河口域の水面形の時間変 化を観測し、これより水面形の時間変化に表れる河床形 状の変化過程の分析 ・解明に努め、適正な河川管理に活 かしたいと考えている5)。

\section{参考文献}

1）宇民正，上野鉄男，木下良作，松本直也，室本孝之：斐伊川 における洪水流と河床形状の同時計測，水工学論文集，第47 巻, pp. 739-746, 1994.

2) 宇民正，上野鉄男，木下良作，鈴木篤，佐近裕之，笠見紀 之: 斐伊川における砂州の動態観測, 水工学論文集, 第42巻, pp. 1099-1104, 1998.

3）吉川秀夫編著 : 流砂の水理学, 丸善株式会社, 1985

4）福岡捷二 : 洪水の水理と河道の設計法, 森北出版株式会社, 2005.

5）福岡捷二: 洪水流の水面形観測の意義と水面形に基づく河川 の維持管理技術，河川技術論文集，第12巻，pp. 1-6，2006.

(2006. 9. 30受付) 